\title{
The Toxic Effects of Nanometer Zinc Oxide on Aquatic Organisms
}

\section{(A review)}

\author{
Zhumei Wang ${ }^{1, a}$, Bo Zhang',b, Xuejiao Zhang ${ }^{3, c}$ \\ ${ }^{1}$ Ocean University of China, No.238 Songling Road, LaoShan District, Qingdao, \\ Shandong Province, China \\ ${ }^{2}$ Ocean University of China, No.238 Songling Road, LaoShan District, Qingdao, \\ Shandong Province, China \\ ${ }^{3}$ Ocean University of China, No.238 Songling Road, LaoShan District, Qingdao, \\ Shandong Province, China \\ athorn_apple@foxmail.com, bzhangb93@126.com, 'czi312lc@163.com
}

Keywords: Nano-ZnO; Aquatic organisms; Toxic effect

Abstract. Nano- $\mathrm{ZnO}$ is a typical engineered nanomaterial, which is used in many fields. With its mass production and wide application, more and more nano- $\mathrm{ZnO}$ discharge into the water body. Water ecological environment is facing a huge threat. This article summarizes the toxic effects of nano- $\mathrm{ZnO}$ on different types of aquatic organisms and looks into the directions for further research on the bio-toxicity of nano- $\mathrm{ZnO}$ in aquatic environments.

\section{Introduction}

Nano- $\mathrm{ZnO}$ is a typical nano-material with excellent performance and wide application. Although numerous studies have demonstrated that nano-zinc oxide can cause damage to aquatic ecosystems, the mechanism of its poisoning remains inconclusive [1, 2], Nano-zinc oxide is easily dissolved in aqueous environments, making it highly toxic to aquatic organisms [3, 4]. In this paper, the toxicological effects of nano- $\mathrm{ZnO}$ on aquatic organisms in recent years are summarized for reference in subsequent studies.

\section{Toxic Effects of Nanometer Zinc Oxide on Algae}

Some research showed that nano- $\mathrm{ZnO}$ exposure significantly inhibited the growth of algae [5], such as Selenastrum capricornutum [6]. Studies have also shown that nano- $\mathrm{ZnO}$ caused a decrease in chlorophyll a content and a decrease in protein content in Chlorella cells [7]. In addition, the exposure of nano-ZnO can also cause changes in the morphology of Chlorella and the destruction of its membrane integrity [8].Miller et al. [9] tested the effects of nano-ZnO on population growth rates of four species (Skeletonema marinoi, Thalassiosira pseudonana, Dunaliella tertiolecta, Isochrysis galbana) of marine phytoplankton representing three major coastal groups (diatoms, chlorophytes, and prymnesiophytes), found that nano- $\mathrm{ZnO}$ inhibits the population growth rate of all four marine phytoplankton species. Manzo et al. [10] found that nano-ZnO exposure had a significant effect on the growth rate of $D$. tertiolecta. Wong et al. [11] found that nano- $\mathrm{ZnO}$ is toxic to Skeletonema 
costatuma and T. pseudonana. In addition, Peng et al. [12] also found that the growth of Chaetoceros gracilis was completely stopped after exposure of $10 \mathrm{mg} \mathrm{L}^{-1}$ nano- $\mathrm{ZnO}$ for 24 hours, while Phaeodactylum tricornutum continued to grow at a slow rate.

Table 1 The Toxic Effect of Nanometer Zinc Oxide on Algae

\begin{tabular}{|c|c|c|c|c|c|}
\hline Partical size[nm] & Test species & $\begin{array}{l}\text { Exposure } \\
\text { duration }\end{array}$ & $\begin{array}{c}\text { Concentration } \\
\qquad\left[\mathrm{mg} \mathrm{L}^{-1}\right]\end{array}$ & Results & References \\
\hline $50-70$ & P. subcapitata & $72 \mathrm{~h}$ & $\mathrm{EC}_{50} 0.042$ & & [13] \\
\hline 30 & P. subcapitata & $72 \mathrm{~h}$ & $\mathrm{IC}_{50} 0.068$ & & {$[14]$} \\
\hline \multirow{4}{*}{$20-30$} & S. marinoi & $96 \mathrm{~h}$ & 1.0 & $\begin{array}{c}\text { growth rate was reduced } \\
\text { by a factor of } 2\end{array}$ & \multirow{4}{*}{ [9] } \\
\hline & T. pseudonana & $96 \mathrm{~h}$ & 0.5 & $\begin{array}{c}\text { growth rate was } \\
\text { significantly reduced }\end{array}$ & \\
\hline & D. tertiolecta & $96 \mathrm{~h}$ & 1.0 & $\begin{array}{c}\text { growth rate was } \\
\text { significantly reduced }\end{array}$ & \\
\hline & I. galbana & $96 \mathrm{~h}$ & 1.0 & $\begin{array}{c}\text { growth rate was } \\
\text { significantly reduced }\end{array}$ & \\
\hline$<\mathbf{1 0 0}$ & D. tertiolecta & $4 \mathrm{~d}$ & $\mathrm{EC}_{50} 1.94$ & & {$[10]$} \\
\hline \multirow{2}{*}{20} & S. costatuma & $96 \mathrm{~h}$ & $\mathrm{LC}_{50} 4.56$ & & \multirow{2}{*}[11]{} \\
\hline & T. pseudonana & $96 \mathrm{~h}$ & $\mathrm{LC}_{50} 2.36$ & & \\
\hline \multirow{3}{*}{$6 、 16$} & T. pseudonana & $>100 \mathrm{~h}$ & 10 & $\begin{array}{l}\text { cell division rate was } \\
\text { significantly reduced }\end{array}$ & \multirow{3}{*}[12]{} \\
\hline & C. gracilis & $>100 \mathrm{~h}$ & 10 & $\begin{array}{l}\text { completely stopped after } \\
\qquad 24 \mathrm{~h}\end{array}$ & \\
\hline & P. tricornutum & $>100 \mathrm{~h}$ & & $\begin{array}{c}\text { continued to grow at a } \\
\text { slow rate }\end{array}$ & \\
\hline 20 & Chlorella & $6 \mathrm{~d}$ & $\mathrm{EC}_{30} 20$ & & {$[5]$} \\
\hline 30 & Chlorella & $96 \mathrm{~h}$ & $\mathrm{EC}_{50} 2.41$ & & {$[7]$} \\
\hline
\end{tabular}

\section{The toxic effect of nano-zinc oxide on arthropods}

The toxicity of nano- $\mathrm{ZnO}$ to aquatic arthropods is mainly aimed at Daphnia magna and Thamnocephalus platyurus. In addition, studies have shown that the $96 \mathrm{~h} \mathrm{EC}_{50}$ value of nano-ZnO to Elasmopus rapax was $1.19 \mathrm{mg} \mathrm{L}^{-1}$, to Tigriopus japonicus was $0.85 \mathrm{mg} \mathrm{L}^{-1}$ [11]. 
Table 2 The Toxic Effect of Nanometer Zinc Oxide on Arthropods

\begin{tabular}{|c|c|c|c|c|}
\hline Partical size[nm] & Test species & Exposure duration & $\begin{array}{c}\text { Concentration } \\
\qquad\left[\mathrm{mg} \mathrm{L}^{-1}\right]\end{array}$ & References \\
\hline \multirow{2}{*}{$50-70$} & D. magna & $48 \mathrm{~h}$ & $\mathrm{LC}_{50} 3.2$ & \multirow{2}{*}[15]{} \\
\hline & T. platyurus & $24 \mathrm{~h}$ & $\mathrm{LC}_{50} 0.18$ & \\
\hline$<200$ & D. magna & $48 \mathrm{~h}$ & $\mathrm{EC}_{50} 7.5$ & {$[16]$} \\
\hline \multirow{2}{*}{70} & D. magna & $48 \mathrm{~h}$ & $\mathrm{EC}_{50} 2.6$ & \multirow{2}{*}[17]{} \\
\hline & T. platyurus & $24 \mathrm{~h}$ & $\mathrm{LC}_{50} 0.14$ & \\
\hline \multirow{2}{*}{20} & T. japonicus & $96 \mathrm{~h}$ & $\mathrm{LC}_{50} 0.85$ & \multirow{2}{*}{ [11] } \\
\hline & E. rapax & $96 \mathrm{~h}$ & $\mathrm{LC}_{50} 1.19$ & \\
\hline
\end{tabular}

\section{The toxic effect of nano zinc oxide on molluses}

Some studies on bivalves found that exposure to nano- $\mathrm{ZnO}$ increased the respiratory rate of Mytilus galloprovincialis [18, 19]. Some have observed loss of mitochondrial ridges, increased number of cytoplasmic vesicles, and disruption of mitochondrial cell membranes, and changes in GR activity in Crassostrea gigas [20]. Studies of two freshwater mussels have shown that nano-ZnO leads to increased zinc accumulation, MT and LPO levels in digestive glands of Elliptio complanata [21], increased MT levels, tissue Protease D and SOD activity in Unio tumidus [22].

In addition, some studies on gastropoda have found that Lymnaea luteola exposed to nano-ZnO after $96 \mathrm{~h}$, the GSH, GST, and GSH-Px in digestive glands are significantly reduced, whereas MDA and CAT are significantly elevated and cause DNA damage [23]. 
Table 3 The Toxic Effects of Nanometer Zinc Oxide on Molluscs

\begin{tabular}{|c|c|c|c|c|c|}
\hline $\begin{array}{l}\text { Partical } \\
\text { size[nm] }\end{array}$ & Test species & $\begin{array}{l}\text { Exposure } \\
\text { duration }\end{array}$ & $\begin{array}{c}\text { Concentration } \\
\qquad\left[\mathrm{mg} \mathrm{L}^{-1}\right]\end{array}$ & Results & References \\
\hline 50 & L. luteola & $96 \mathrm{~h}$ & 0.032 & $\begin{array}{l}\text { GSH, GST, GSH-Px significantly } \\
\text { decreased, MDA, CAT increased } \\
\text { significantly, DNA damage }\end{array}$ & {$[23]$} \\
\hline 20-30 & M. galloprovincialis & $12 \mathrm{wk}$ & $0.1-2$ & Breathing rate increased & {$[18]$} \\
\hline 28-88 & C. gigas & $96 \mathrm{~h}$ & $\mathrm{LC}_{50} 30$ & $\begin{array}{l}\text { Mitochondrial damage, changes in GR, } \\
\text { protein thiol levels, LPO and GSH-Px } \\
\text { activity }\end{array}$ & {$[20]$} \\
\hline 50 & C. Cahayensis & $14 \mathrm{~d}$ & $0.1-2.0$ & $\begin{array}{l}\text { Increased SOD, CAT activity and MDA } \\
\text { content } \\
\text { GST activity is significantly inhibited }\end{array}$ & {$[24]$} \\
\hline 35 & E. complanata & $21 \mathrm{~d}$ & 0.002 & $\begin{array}{l}\text { Zinc accumulation in digestive glands, } \\
\text { elevated levels of MT and LPO }\end{array}$ & {$[21]$} \\
\hline 35 & U. tumidus & $14 \mathrm{~d}$ & $\begin{array}{c}0.2 \\
(\mathrm{Zn})\end{array}$ & $\begin{array}{l}\text { Increased levels of MT, SOD, and } \\
\text { cathepsin D activity and decreased } \\
\text { protein carbonyl levels }\end{array}$ & {$[22]$} \\
\hline
\end{tabular}

\section{The toxic effect of nano-zinc oxide on vertebrate animals}

The toxicity of nano-zinc oxide to aquatic vertebrates is mainly for Danio rerio, especially embryo hatching [25-27]. There are also studies on other fish, such as Cyprinus carpio [28], Carassius auratus [29] and Oreochromis niloticus [30].

Table 4 The Toxic Effect of Nanometer Zinc Oxide on Vertebrate

\begin{tabular}{|c|c|c|c|c|c|}
\hline $\begin{array}{l}\text { Partical } \\
\text { size[nm] }\end{array}$ & $\begin{array}{c}\text { Test } \\
\text { species }\end{array}$ & $\begin{array}{l}\text { Exposure } \\
\text { duration }\end{array}$ & $\begin{array}{l}\text { Concentration } \\
\qquad\left[\mathrm{mg} \mathrm{L}^{-1}\right]\end{array}$ & Results & References \\
\hline 20 & D. rerio & $96 \mathrm{~h}$ & $\begin{array}{l}84 \mathrm{hpf} \mathrm{EC}_{50} \\
\quad 23.06\end{array}$ & & {$[31]$} \\
\hline 9 & D. rerio & $96 \mathrm{~h}$ & 1.0 & The $96 \mathrm{hpf}$ hatching rate was only $3.1 \pm 2.7 \%$ & {$[25]$} \\
\hline 30 & C. carpio & $30 \mathrm{~d}$ & 50 & $\begin{array}{l}\text { Histopathological changes, GSH, SOD activity } \\
\text { decreased, protein carbonyl, MDA content increased }\end{array}$ & {$[28]$} \\
\hline$<\mathbf{5 0}$ & C. auratus & $14 \mathrm{~d}$ & $1 、 12.5 、 50$ & $\begin{array}{l}\text { MDA content increases, SOD activity is inhibited, } \\
\text { GSH changes }\end{array}$ & [29] \\
\hline $\begin{array}{c}10-30 \\
100\end{array}$ & O. niloticus & $14 \mathrm{~d}$ & 1、 10 & SOD, CAT, and GSH levels fluctuate significantly & {$[30]$} \\
\hline
\end{tabular}




\section{Outlooks}

With the wide application of nano- $\mathrm{ZnO}$, people are paying more and more attention to its potential harm to organisms and possible environmental risks. However, most of the current researches are conducted under laboratory simulation conditions. The main reason is that nano- $\mathrm{ZnO}$ has unique mechanical, optical, magnetic, and thermal properties, physical and chemical parameters, and the environmental behavior of nano- $\mathrm{ZnO}$ is affected by many factors, but chemical analysis methods are limited and can not clearly analyze its changes in the environment.

Although there are many researches on nano- $\mathrm{ZnO}$, the toxic mechanism of nano- $\mathrm{ZnO}$ also needs more in-depth study. Combined with the current toxicological studies of nano-ZnO on aquatic organisms and the aforementioned limitations, the following research work can consider the following aspects:

(1) Improve the corresponding chemical analysis methods. After the nano- $\mathrm{ZnO}$ enter the environment, its fate and transformation is extremely complicated. It is important to fully detect and characterize the morphology and changes of the nano-ZnO in the environment. Many studies believe that dissolved nanoparticles are important factors that cause biological effects. Therefore, understanding the dissolution kinetics of nanoparticles can help assess their environmental and health risks.

(2) The effects of nano-zinc oxides on the marine organisms and toxic mechanisms must be explored at different levels of ecosystems, communities, populations, individuals, cells, and gene proteins. Zinc has an extremely strong assimilation efficiency, and its toxic effects on the food chain transmission pathway and gene expression are studied, which helps humans to control this process and reduce the damage of nanomaterials to the ecosystem.

(3) Nanomaterials often appear in the form of compound pollution in the natural water environment, and are affected by many factors such as temperature, salinity, $\mathrm{pH}$, etc. Therefore, it is necessary to strengthen the research on the combined toxicity of nano-zinc oxide and other pollutants. To study the toxic mechanism of nano-zinc oxide in order to protect the marine ecosystem, maintain human health, and promote nanotechnology to be safer, more efficient, and more effective.

\section{Acknowledgements}

This work was financially supported by the Shanghai Natural Science Foundation (0666666), Innovation Program of Shanghai Municipal Education Commission (060000) and Shanghai Leading Academic Discipline Project of Shanghai Municipal Education Commission (0555555).

\section{Reference}

[1] H. Ma, P. L. Williams, S. A. Diamond, Ecotoxicity of manufactured ZnO nanoparticles--a review. Environmental Pollution 172, 76 (2013).

[2] A. Ivask et al., Mechanisms of toxic action of $\mathrm{Ag}, \mathrm{ZnO}$ and $\mathrm{CuO}$ nanoparticles to selected ecotoxicological test organisms and mammalian cells in vitro: a comparative review. Nanotoxicology 8, 57-71 (2014).

[3] Thabitha et al., Determination of the mechanism of photoinduced toxicity of selected metal oxide nanoparticles $\left(\mathrm{ZnO}, \mathrm{CuO}, \mathrm{Co}_{3} \mathrm{O}_{4}\right.$ and $\left.\mathrm{TiO}_{2}\right)$ to E.coli bacteria. Acta Scientiae Circumstantiae (English) 25, 882 (2013).

[4] R. J. Barnes, R. Molina, J. Xu, P. J. Dobson, I. P. Thompson, Comparison of $\mathrm{TiO}_{2}$ and $\mathrm{ZnO}$ nanoparticles for photocatalytic degradation of methylene blue and the correlated inactivation of gram-positive and gram-negative bacteria. Journal of Nanoparticle Research 15, 1432 (2013). 
[5] J. Ji, Z. Long, D. Lin, Toxicity of oxide nanoparticles to the green algae Chlorella sp. Chemical Engineering Journal 170, 525-530 (2011).

[6] J. X. Liu, Q. P. Du, Z. M. Chen et al. Toxicities of ZnO nanoparticles on Selenastrum capricornutum and its distributions in intra-and extra-cells. Asian Journal of Ecotoxicology(in Chinese) 11, 103-110 (2016)

[7] X L. Jin, N. Zhang, X. Li et al. Toxic effects of four nanoscale oxides on Chlorellavulgaris. Journal of Tianjin University of Technology 27, 58-62 (2011)

[8] P. Chen, B. A. Powell, M. Mortimer, P. C. Ke, Adaptive Interactions between Zinc Oxide Nanoparticles and Chlorella sp. Environmental Science \& Technology 46, 12178-12185 (2012).

[9] R. J. Miller et al., Impacts of metal oxide nanoparticles on marine phytoplankton. Environmental Science \& Technology 44, 7329 (2010).

[10] S. Manzo, M. L. Miglietta, G. Rametta, S. Buono, G. Di Francia, Toxic effects of ZnO nanoparticles towards marine algae Dunaliella tertiolecta. Sci Total Environ 445-446, 371-376 (2013).

[11] S. W. Wong, P. T. Leung, A. B. Djurisic, K. M. Leung, Toxicities of nano zinc oxide to five marine organisms: influences of aggregate size and ion solubility. Anal Bioanal Chem 396, 609-618 (2010).

[12] X. Peng, S. Palma, N. S. Fisher, S. S. Wong, Effect of morphology of ZnO nanostructures on their toxicity to marine algae. Aquat Toxicol 102, 186-196 (2011).

[13] V. Aruoja, H. C. Dubourguier, K. Kasemets, A. Kahru, Toxicity of nanoparticles of CuO, ZnO and $\mathrm{TiO}_{2}$ to microalgae Pseudokirchneriella subcapitata. Sci Total Environ 407, 1461-1468 (2009).

[14] N. M. Franklin et al., Comparative Toxicity of Nanoparticulate $\mathrm{ZnO}$, Bulk ZnO, and ZnCl2to a Freshwater Microalga (Pseudokirchneriella subcapitata): The Importance of Particle Solubility. Environmental Science \& Technology 41, 8484-8490 (2007).

[15] M. Heinlaan, A. Ivask, I. Blinova, H. C. Dubourguier, A. Kahru, Toxicity of nanosized and bulk $\mathrm{ZnO}, \mathrm{CuO}$ and $\mathrm{TiO} 2$ to bacteria Vibrio fischeri and crustaceans Daphnia magna and Thamnocephalus platyurus. Chemosphere 71, 1308-1316 (2008).

[16] K. Wiench et al., Acute and chronic effects of nano- and non-nano-scale $\mathrm{TiO}_{2}$ and $\mathrm{ZnO}$ particles on mobility and reproduction of the freshwater invertebrate Daphnia magna. Chemosphere 76, 1356-1365 (2009).

[17] I. Blinova, A. Ivask, M. Heinlaan, M. Mortimer, A. Kahru, Ecotoxicity of nanoparticles of CuO and $\mathrm{ZnO}$ in natural water. Environ Pollut 158, 41-47 (2010).

[18] S. K. Hanna, R. J. Miller, E. B. Muller, R. M. Nisbet, H. S. Lenihan, Impact of engineered zinc oxide nanoparticles on the individual performance of Mytilus galloprovincialis. PLoS One $\mathbf{8}$, e61800 (2013).

[19] E. B. Muller, S. K. Hanna, H. S. Lenihan, R. J. Miller, R. M. Nisbet, Impact of engineered zinc oxide nanoparticles on the energy budgets of Mytilus galloprovincialis. Journal of Sea Research 94, 29-36 (2014).

[20] R. Trevisan et al., Gills are an initial target of zinc oxide nanoparticles in oysters Crassostrea gigas, leading to mitochondrial disruption and oxidative stress. Aquat Toxicol 153, 27-38 (2014).

[21] F. Gagne, P. Turcotte, J. Auclair, C. Gagnon, The effects of zinc oxide nanoparticles on the metallome in freshwater mussels. Comp Biochem Physiol C Toxicol Pharmacol 158, 22-28 (2013).

[22] H. Falfushynska, L. Gnatyshyna, I. Yurchak, I. Sokolova, O. Stoliar, The effects of zinc 
nanooxide on cellular stress responses of the freshwater mussels Unio tumidus are modulated by elevated temperature and organic pollutants. Aquat Toxicol 162, 82-93 (2015).

[23] D. Ali, S. Alarifi, S. Kumar, M. Ahamed, M. A. Siddiqui, Oxidative stress and genotoxic effect of zinc oxide nanoparticles in freshwater snail Lymnaea luteola L. Aquat Toxicol 124-125, 83-90 (2012).

[24] H. Liu, A. Q. Jiang, W. M. Wang. Ecotoxicity of low concentration micro/nano ZnO exposure on Cipangopaludina Cahayensis. Journal of Agro-Environment Science 36, 474-480 (2017)

[25] N. R. Brun, M. Lenz, B. Wehrli, K. Fent, Comparative effects of zinc oxide nanoparticles and dissolved zinc on zebrafish embryos and eleuthero-embryos: Importance of zinc ions. Science of The Total Environment 476-477, 657-666 (2014).

[26] L. Liu, Q. F. Zhao, K. X. Jin et al. Toxic Effect of Nano-ZnO in Liver of Zebrafish. Environmental science 36, 3884-3891 (2015)

[27] L. N. Lv. Harbin University of Engineering (2013)

[28] L. Hao, L. Chen, J. Hao, N. Zhong, Bioaccumulation and sub-acute toxicity of zinc oxide nanoparticles in juvenile carp (Cyprinus carpio): A comparative study with its bulk counterparts. Ecotoxicology and Environmental Safety 91, 52-60 (2013).

[29] Z. X. Hu, L. Liu, Y. H. Guo et al. Toxicity of nano and micro ZnO on Carassius auratus. Journal of Nanjing University (Natural Science) 50, 425-430 (2014)

[30] H. Kaya et al., Effects of zinc oxide nanoparticles on bioaccumulation and oxidative stress in different organs of tilapia (Oreochromis niloticus). Environ Toxicol Pharmacol 40, 936-947 (2015).

[31] X. Zhu, J. Wang, X. Zhang, Y. Chang, Y. Chen, The impact of ZnO nanoparticle aggregates on the embryonic development of zebrafish (Danio rerio). Nanotechnology 20, 195103 (2009). 